\title{
QUATERNARY AMMONIUM COMPOUNDS
}

\section{A NEW TECHNIQUE FOR THE STUDY OF THEIR BACTERICIDAL ACTION AND THE RESULTS OBTAINED WITH CETAVLON* (CETYLTRIMETHYLAMMONIUM BROMIDE)}

\author{
BY G. E. DAVIES \\ From Imperial Chemical Industries Ltd,, Biological Laboratories, \\ Hexagon House, Blackley, Manchester
}

\section{INTRODUCTION}

In vitro bactericidal action

Since the publication in 1935 of a paper by Domagk, which drew attention to the bactericidal properties of high-molecular quaternary ammonium salts, there has been a great deal of discussion on the best methods of testing these compounds and many conflicting statements concerning their action have appeared in the literature. Some writers (e.g. Heinemann, 1937; Du Bois \& Dibblee, 1946; Kenner, Quisno, Foter \& Gibby, 1946; Green \& Birkeland, 1941; Blubaugh, Grewe, Botts \& Helvig, 1940; Quisno \& Foter, 1946) have claimed that they are extremely potent, while the view of the opposing school is exemplified by the statement of McCulloch (1947), that '... quaternary ammonium compounds probably do not disinfect even in sufficient concentration and the absence of large amounts of organic matter' (see also Klarmann \& Wright, 1946, 1948). However, all writers agree $(a)$ that the phenol-coefficients of the compounds are very high, and $(b)$ that the results obtained by the phenol coefficient technique are variable and difficult to interpret.

\section{Reasons advanced for inconsistencies in the results of phenol-coefficient tests with quaternary ammonium compounds}

In the phenol-coefficient test, the bactericidal activity of the compound under examination is compared with that of phenol. A fixed amount of a bacterial culture is added to a solution of the antiseptic and at various intervals of time one standard loopful of the mixture is transferred to a tube of broth. With most antiseptics the results are clear-cut and unambiguous, but with quaternary compounds it frequently happens that on incubation a particular tube exhibits growth, while tubes representing stronger solutions, or the same solution after a shorter interval of contact, show no growth. Such occurrences are referred to in the

* The name approved by the British Pharmacopoeia Commission for this substance is Cetrimide. literature as 'wild plusses' - a particularly apt term. Quisno \& Foter (1946) suggested that these inconsistencies might be due to the effect of a colloidal precipitate formed when the quaternary compound is added to broth. But Barnes (1942) found that broth had a negligible effect on the bactericidal action of Cetavlon (cetyltrimethylammonium bromide), and indeed the powerful bacteriostatic action of the compounds in the presence of broth, which has not been questioned, seems to confirm his statement. It is unlikely therefore that the inconsistencies mentioned are caused by the presence of broth.

The theory that viable bacterial cells are not uniformly distributed in the liquid but are massed against the walls of the tube was advanced by Klarmann \& Wright (1946). If this effect did in fact influence the result it would mean that the body of the liquid should be practically free from cells. But there is no diminution in total bacterial count (as distinct from viable count), although clumping does occur, when a suspension of cells in a quaternary compound is transferred through a series of tubes, being poured from one into the other. Under some conditions the cells do tend to adhere to the glass but they are removed again by gentle shaking. The adherence of cells to the walls of the tube is therefore quantitatively insignificant.

The powerful bacteriostatic activity of quaternary compounds has also been suggested as a possible reason for the discrepancies observed (Quisno, Gibby \& Foter, 1946a). It is difficult to see the reasoning behind such statements, since presumably any error would be constant in all tests performed under standard conditions. Even though the results would be erroneous (in that they would attribute an undue activity to the compound) they should at least be consistently wrong.

McCulloch, Hauge \& Migaki $(1948 a, b)$ have put forward an alternative suggestion, namely, that quaternary compounds very rapidly reduce the viable count of a bacterial population, partly by killing the cells and partly by clumping them. This implies that there are very few potentially viable 
bacterial particles in the suspension, and that the probability of these being picked up by a loop is remote, but that such does occur occasionally, producing the 'wild plusses' so characteristic of tests on quaternary compounds. This appears to be the most likely explanation of the variability, and is borne out by our own experiments. Du Bois (1947) has made a similar suggestion and explains the persistence of a few survivors by assuming that they are those organisms actually inside the clumps and not reached by the quaternary compound. Quisno, Foter \& Rubenkoenig (1947) believe that the orientation of the molecules at the air/water interface allows a few organisms to escape the lethal action of the compounds.

\section{Suggested modifications in method of testing}

The difficulties and inconsistencies of the phenol-coefficient test have led to numerous modifications both in the media used and in the technique of sampling. It may be said at the outset that any test based on an 'all or none' reaction, i.e. a test which gives the same result with few or many survivors, will lead to wrong conclusions.

Media designed to reduce the bacteriostatic activity of quaternary compounds have included those containing Bacto Oxgall (Klarmann \& Wright, 1948), lecithin and Tween (Quisno, Gibby \& Foter, 1946b), agar (Quisno et al. 1946a) and sterile evaporated milk (McCulloch et al. 1948a,b). All these media are satisfactory in that they fulfil the two essential conditions of: (1) reducing bacteriostatic activity, and (2) not interfering with growth of the organism. Soaps and anionic detergents have also been used (Valko \& Du Bois, 1944) but are not entirely successful because, in some cases, they themselves exert an antibacterial action. Efforts to overcome bacteriostasis by simple dilution are not satisfactory since it can be shown that organisms which have once been in contact with a strong solution of an antiseptic are more susceptible to its bacteriostatic action than organisms which have not been so treated (Davies \& Fishburn, 1946; Graydon \& Biggs, 1942). All tests based on 'all or none' techniques without inactivator give figures indicating very high activity. Similar tests using inactivator indicate a very low activity (e.g. a $1: 2000$ solution may show no apparent kill after $15 \mathrm{~min}$.).

Numerous modifications in technique have been used. Only those which illustrate the present argument will be mentioned. Kenner et al. (1946) used the F.D.A. phenol coefficient test, but instead of subculturing into broth they injected the germicide/bacteria mixture into mice and examined the heart blood for the organism $5 \mathrm{hr}$. after inoculation. Salmonella typhi murium was used as test organism. This is commonly carried by laboratory mice and natural infections may have influenced the result. The test as performed by these authors suffers from the added defect that the presence of a few surviving bacteria would not be noticed, since they would probably not be present in sufficient numbers in the heart blood after $5 \mathrm{hr}$. Close agreement was obtained with results given by the F.D.A. test, the fallacies of which have been pointed out already.

Klarmann \& Wright (1948) used a semi-micro in vitro method in which the whole of the germicide/ bacteria mixture was used as the inoculum. Here again the survival of a very few organisms would confuse the results. Their filter-paper test (1946), in which a solution of the test compound is added to a piece of filter-paper saturated with culture and the paper transferred to a neutralizing medium, has been criticized by Du Bois (1947), who showed that the filter-paper adsorbs appreciable amounts of the quaternary compound thus reducing the concentration available for action on the bacteria. The large amount of compound transferred with the paper is difficult to inactivate and for sensitive organisms such as the staphylococci, dilution plus neutralization must be used.

Mallmann \& Leavitt (1948) and Mallmann \& Hanes (1945) have used the 'use-dilution' technique in which a microscope slide coated with a dry film of bacteria is dipped into a solution of the quaternary compound and then washed in water. Considerable numbers of bacteria are probably lost by the detergent action of the compound and the results may thus be rendered meaningless, since the apparent kill will include those which have been lost in the transfer but not necessarily killed.

Nagel (1940), Miller (1942) and Du Bois \& Dibblee (1947) employed a technique in which the treated cells were repeatedly washed on the centrifuge with sterile water after which they were suspended in broth in the centrifuge tubes. This test suffers from the defect that it is impossible to find out what happens during the first few minutes of contact. since it is not possible to stop the reaction at any desired point. What actually occurs is that the cells are submitted to a series of solutions of quaternary compounds of decreasing concentration. In addition, it does not follow that simple washing necessarily removes all the adsorbed quaternary compound.

Some of these tests, in particular those of Klarman \& Wright, have indicated a decreased potency. Others have confirmed results obtained by the F.D.A. technique.

Quantitative experiments have been carried out by McCulloch et al. $(1948 a, b)$, who have used methods indicating the rate of destruction of the bacteria. These authors have shown that there is a great reduction in plate counts during the first 
few minutes of contact between the quaternary solution and bacteria. This is followed by a much slower rate of kill. McCulloch's explanation for this phenomenon is that the initial rapid drop in count is a summation of the effects due to killing and those due to clumping. Thus, several viable bacteria may give rise to only one colony. Du Bois (1947) has suggested that the later, slower rate of kill, is due to penetration of the compound into these clumps.

\section{Sporicidal action}

On this subject also there are many conflicting statements in the literature.

No technical details are given in the paper by Green \& Birkeland (1941), who claimed that Ceepryn was an effective and practical germicide against spores of various aerobic and anaerobic bacteria. Du Bois \& Dibblee (1946) claimed that Tetrosan in dilutions of $1: 5000$ to $1: 20,000$ killed $60-75 \%$ of spores of Bacillus metiens ( $=B$. cereus) almost immediately at $80^{\circ} \mathrm{C}$, while the remainder were not killed even after $6 \mathrm{hr}$. contact. They explained these results by assuming that the original population was made up of spores of very different resistances. No effort was made to re-grow and re-test the survivors. McCulloch et al. (1948a) reported that no significant reduction in count occurred during $2 \mathrm{hr}$. contact between $2 \%$ hyamine and spores of $B$. subtilis. Sterile evaporated milk was used in this experiment to guard against errors caused by bacteriostasis, a precaution which the other authors omitted. That this precaution is of great importance in experiments of this type has recently been shown by Kivela, Mallmann \& Churchill (1948), who found that spores of B. subtilis which had apparently been killed by quaternary compounds gradually recovered when repeatedly shaken and washed on the centrifuge until the viable counts reached their original values. The process of recovery was followed by electrophoresis experiments which demonstrated that as washing proceeded the positive electric charge gained by the spores in presence of the quaternary compounds was gradually reduced, neutralized, and finally restored to the original negative charge of untreated spores.

\section{EXPERIMENTAL WORK}

The object of the work described below was to provide, as far as laboratory methods will allow, an assessment of the anti-bacterial properties of quaternary ammonium compounds. The only quaternary ammonium compound examined in any detail has been Cetavlon (all the samples used in this work contained $80-85 \%$ cetyltrimethylammonium bromide), but there is no reason to believe that any of the other quaternary compounds of this type behave differently.

Consideration of the errors discussed above enables one to enunciate the requirements necessary to give a true indication of the bactericidal action of quaternary ammonium compounds. These are:

(1) A sufficiently large sample must be taken from the germicide/bacteria mixture to ensure that a fair proportion of the clumped bacteria is included.

(2) Some means of breaking up these clumps must be adopted.

(3) The bacteriostatic activity of the quaternary compound must be neutralized by a substance which does not interfere with the growth of the testorganism.

(4) The method should indicate the actual numbers of surviving cells.

To devise a suitable test it was first of all necessary to adopt some means of achieving requirements (2) and (3) above.

\section{Method of removing clumps}

A series of trials showed that shaking the cell suspension by hand with a $1 \%$ solution of Lubrol $\mathrm{W}^{*}$ containing glass beads was an efficient method of breaking up the large clumps as the results in Table 1 show.

Table 1. Disappearance of clumps of Staphylococcus aureus on shaking with Lubrol $W$ and glass beads

Treatment of cells

5 min. contact with $\mathrm{M} / 10,000$ Cetavlon

5 min. contact with distilled water

5 min. in $\mathrm{M} / 10,000$ Cetavlon; shaken for $1 \mathrm{~min}$. in $1 \%$ Lubrol W with glass beads

Du Bois (1947) has suggested that organisms inside these clumps survive because they have not been long enough in contact with the quaternary ammonium compound to be killed. To test this hypothesis an experiment was conducted in which the mixture of bacteria and quaternary ammonium compound was shaken with glass beads during the period of contact. Microscopical examination of slides taken during the course of the experiment showed that no clumps formed, and the results in Table 2 show that there were no persistent survivors. However, in all subsequent experiments the clumps were allowed to form as they presumably do under actual conditions of use.

* Lubrol W is described as 'A fatty glycol-ethyleneoxide-condensate'. 


\section{Neutralization of bacteriostatic activity}

Here again, Lubrol $W$ was found to be an effective agent. Staphylococcus aureus failed to grow in broth containing 1 in $10^{5}$ Cetavlon but grew in the presence of 1 in $10^{4}$ Cetavlon if $1 \%$ of Lubrol W was present. Horse serum (10\%) and agar (2\%) gave similar results. Lubrol $W$ was chosen for routine use because it is more stable than serum (it can be sterilized by autoclaving) and is more convenient to handle than agar. It does not interfere with the growth of bacteria; more than twenty strains of various species grew well in broth containing $1 \%$ Lubrol W.

\section{Lubrol technique for determining the rate of kill of bacteria by quaternary compounds}

(a) Preparation of inoculum. $0.5 \mathrm{ml}$. of a $24 \mathrm{hr}$. broth culture was pipetted on to $5 \mathrm{ml}$. of agar contained in a $50 \mathrm{ml}$. conical Pyrex flask. After give plates representing $10^{-6}, 10^{-7}$, and $10^{-8}$ of the initial population.

Note. A separate pipette must be used for each manipulation or confusing and inaccurate results will be obtained.

\section{RESULTS}

The bactericidal action of a range of concentrations of Cetavlon on four species of bacteria was determined. It will be seen (Table 3) that the peculiar rate of kill of quaternary compounds becomes manifest only in dilute solutions-for Grampositive bacteria at $0.003 \%$ or weaker, and for Gram-negative bacteria at $0.007 \%$ or weaker. At these concentrations nearly all the bacteria are killed during the first few minutes but the survivors are killed at a much slower rate. In stronger solutions $(0.03 \%$ or more) there are no survivors after the first few minutes. These experiments were

Table 2. Numbers of Staphylococcus aureus surviving when exposed to Cetavlon for 30 min. with and without continual agitation during exposure so that clumps do not form

\begin{tabular}{|c|c|c|c|c|c|c|c|c|}
\hline \multirow[b]{2}{*}{$\begin{array}{l}\text { Time of } \\
\text { exposure } \\
\text { (min.) }\end{array}$} & \multicolumn{8}{|c|}{ Treatment of Staph. aureus cells } \\
\hline & $\begin{array}{c}\text { Shaken, } \\
\text { with } \\
0.0015 \% \\
\text { Cetavlon }\end{array}$ & $\begin{array}{c}\text { Not } \\
\text { shaken, } \\
\text { with } \\
0.0015 \% \\
\text { Cetavlon }\end{array}$ & $\begin{array}{c}\text { Shaken, } \\
\text { with } \\
\text { water }\end{array}$ & $\begin{array}{c}\text { Not } \\
\text { shaken, } \\
\text { with } \\
\text { water }\end{array}$ & $\begin{array}{c}\text { Shaken, } \\
\text { with } \\
0.006 \% \\
\text { Cetavlon }\end{array}$ & $\begin{array}{c}\text { Not } \\
\text { shaken, } \\
\text { with } \\
0.006 \% \\
\text { Cetavlon }\end{array}$ & $\begin{array}{c}\text { Shaken, } \\
\text { with } \\
\text { water }\end{array}$ & $\begin{array}{c}\text { Not } \\
\text { shaken, } \\
\text { with } \\
\text { water }\end{array}$ \\
\hline 0 & $1 \times 10^{7}$ & $1 \times 10^{7}$ & $1 \times 10^{7}$ & $1 \times 10^{7}$ & $2 \times 10^{8}$ & $2 \times 10^{8}$ & $2 \times 10^{8}$ & $2 \times 10^{8}$ \\
\hline $\mathbf{5}$ & 216 & 19,800 & $1.9 \times 10^{7}$ & $9 \times 10^{6}$ & 6 & 6,180 & 一 & - \\
\hline 15 & 6 & 9,000 & $1.6 \times 10^{7}$ & $1.3 \times 10^{7}$ & 24 & 180 & - & 一 \\
\hline 30 & 0 & 5,400 & $1.9 \times 10^{7}$ & $1.0 \times 10^{7}$ & 0 & 0 & $2 \times 10^{8}$ & $2 \times 10^{8}$ \\
\hline
\end{tabular}

$24 \mathrm{hr}$. incubation at $37^{\circ} \mathrm{C}$. the growth was washed off with $10 \mathrm{ml}$. of distilled water, a few sterile glass beads being used to loosen the growth and break up large clumps. One $\mathrm{ml}$. of this suspension was used as the inoculum. Viable counts were consistently within the limits $1-2 \times 10^{9}$ per ml. for Staph. aureus. Other organisms also gave consistent counts, the limits for each species being at a different level.

(b) Test. One ml. of the inoculum was added to $9 \mathrm{ml}$. of a dilution of the quaternary compound and well mixed. After the desired period of contact the mixture was stirred with a pipette and $1 \mathrm{ml}$. transferred to a $1 \mathrm{oz}$. McCartney bottle containing $5 \mathrm{ml}$. of a sterile $1 \%$ solution of Lubrol W and about 200 glass beads $2 \mathrm{~mm}$. in diameter. The bottle was shaken by hand for $1 \mathrm{~min}$. and allowed to stand a further $4 \mathrm{~min}$. Four tenfold dilutions were plated, $1 \mathrm{ml}$. of each being placed in a sterile Petri dish and $15 \mathrm{ml}$. of molten agar added. After $24 \mathrm{hr}$. at $37^{\circ} \mathrm{C}$. the number of colonies was counted with the aid of an automatic colony counter. The initial inoculum was determined by diluting the culture, first in Lubrol W + glass beads and then in water to repeated with other strains of the same species and substantially the same results were obtained.

\section{The influence of organic materials}

Several authors (e.g. Quisno et al. 1946a; McCulloch, 1947) have shown that the bactericidal action of quaternary compounds is reduced in the presence of organic matter. While this is true, the reduction is not of any great magnitude. Our own experiments show that considerable activity is retained even in the presence of fairly large amounts of blood. Tables 4 and 5 show the bactericidal action of 0.1 and $1 \%$ Cetavlon in the presence of 10 and $90 \%$ horse blood respectively. It was not possible to measure the rate of kill of 0.1 or $1 \%$ Cetavlon in the absence of organic matter owing to the rapidity of action at these concentrations. However, a comparison may be made with the action of a $0.03 \%$ solution (Table 3 ).

In Table 6 the action of $0.1 \%$ Cetavlon on Streptococcus agalactiae in the presence of milk is shown. These results indicate that quaternary ammonium compounds should be satisfactory as adjuncts in the control of bovine mastitis. 
It is concluded from the foregoing experiments that a concentration of Cetavlon of $0.1 \%$ is a very powerful bactericide even in the presence of organic matter.

\section{The action of Cetavlon on spores}

Quaternary ammonium compounds at a concentration of $1 \%$ will not kill bacterial spores at room temperature. Washed spores of $B$. subtilis and five other unidentified sporing bacilli were suspended

\section{Virulence of bacteria surviving the action of weak solutions of Cetavlon}

Even though organisms surviving the action of weak solutions of Cetavlon have, in some way, been protected from contact with a lethal dose of the compound it was considered that their properties may have become so modified as to reduce their virulence, virulence being understood as the power to kill the test animal. If this were indeed the case

Table 3. Bactericidal action of Cetavlon at $20^{\circ} \mathrm{C}$.

\begin{tabular}{|c|c|c|c|c|c|c|}
\hline & \multirow{2}{*}{$\begin{array}{l}\text { Period } \\
\text { of } \\
\text { contact } \\
\text { (min.) }\end{array}$} & \multicolumn{5}{|c|}{ Number of surviving cells per ml. } \\
\hline & & $\begin{array}{c}0.06 \% \\
\text { Cetavlon }\end{array}$ & $\begin{array}{c}0.03 \% \\
\text { Cotavlon }\end{array}$ & $\begin{array}{c}0 \cdot 007 \% \\
\text { Cotavlon }\end{array}$ & $\begin{array}{c}0.003 \% \\
\text { Cetavlon }\end{array}$ & $\begin{array}{c}0.002 \% \\
\text { Cetavlon }\end{array}$ \\
\hline Staph. aureus & $\begin{array}{r}0 \\
5 \\
15 \\
60\end{array}$ & E & $\begin{array}{r}1,000,000,000 \\
0 \\
0 \\
0\end{array}$ & $\begin{array}{r}1,000,000,000 \\
1,800 \\
0 \\
0\end{array}$ & $\frac{-}{-}$ & $\begin{array}{r}1,000,000,000 \\
600,000 \\
12,000 \\
120\end{array}$ \\
\hline Strep. pyogenes & $\begin{array}{r}0 \\
5 \\
10 \\
15 \\
60\end{array}$ & $\begin{array}{l}\text { E } \\
\text { E }\end{array}$ & $\begin{array}{r}5,000,000,000 \\
0 \\
0 \\
0 \\
0\end{array}$ & $\begin{array}{l}\bar{z} \\
\bar{z}\end{array}$ & $\begin{array}{r}5,000,000,000 \\
6,000 \\
1,200 \\
18 \\
6\end{array}$ & $\begin{array}{l}\bar{z} \\
\bar{z}\end{array}$ \\
\hline Bact. coli & $\begin{array}{r}0 \\
5 \\
15 \\
30\end{array}$ & $\begin{array}{l}- \\
- \\
-\end{array}$ & $\begin{array}{r}100,000,000 \\
2,400 \\
0 \\
0\end{array}$ & $\begin{array}{r}100,000,000 \\
3,600 \\
540 \\
0\end{array}$ & $\begin{array}{l}- \\
-\end{array}$ & $\begin{array}{r}100,000,000 \\
120,000 \\
18,000 \\
180\end{array}$ \\
\hline Ps. pyocyanea & $\begin{array}{r}0 \\
5 \\
15 \\
60\end{array}$ & $\begin{array}{r}2,300,000,000 \\
0 \\
0 \\
0\end{array}$ & $\begin{array}{r}2,300,000,000 \\
0 \\
0 \\
0\end{array}$ & $\begin{array}{r}2,300,000,000 \\
55,200 \\
18,000 \\
600\end{array}$ & E & $\begin{array}{l}- \\
z\end{array}$ \\
\hline
\end{tabular}

Table 4. The bactericidal action of $0.1 \%$ Cetavlon in the presence of $10 \%$ horse blood

Time of

$\begin{array}{crr}\begin{array}{c}\text { exposure } \\ \text { (min.) }\end{array} & \text { Ps. pyocyanea } & \text { Bact. coli } \\ 0 & 1,300,000,000 & 86,000,000 \\ 2 & 4,200 & 21,000 \\ 5 & 300 & 300 \\ 15 & 6 & 0 \\ 60 & 6 & 0\end{array}$

Staph. aureus
$1,300,000,000$
12,000
0
0
0

Strep. pyogenes $560,000,000$ in $1 \%$ solutions of Cetavlon, Zephiran (alkyldimethylbenzylammonium chloride), Phemerol ( $p$ tertiary octylphenoxyethyldimethylbenzylammonium chloride) and Ceepryn (cetylpyridinium chloride), and also in distilled water. The initial inoculum was approximately 1 million spores per $\mathrm{ml}$.

No significant drop in count occurred after 3 days' contact when the Lubrol technique was used, although the suspensions in quaternary compounds were apparently sterilized after $1 \mathrm{hr}$. when no precautions were taken to prevent bacteriostasis. A $1 \%$ solution of Cetavlon in $70 \%$ alcohol was also tested. Again no killing was observed. it would obviously be a very valuable property. A rough experiment was carried out to test this hypothesis and it was found that if such a reduction in virulence does occur, it is too small to be important.

Cells of a mouse-virulent strain of Strep. pyogeres were suspended in dilute solutions of Cetavlon for $5 \mathrm{~min}$. and then two samples were taken: $(a) 0.2 \mathrm{ml}$. of the suspension was injected intraperitoneally into each of six mice; (b) the number of surviving organisms was determined by the Lubrol technique. The control tubes consisted of aqueous suspensions of the bacteria. The survival time and the propor- 
tion of animals killed, for a given number of viable cells, was substantially the same whether the organisms had been in contact with the Cetavlon or not.

\section{DISCUSSION}

The true bactericidal activity of quaternary ammonium compounds seems to lie between the two extremes of very high and very low activity indicated in the introduction to this report. A result indicating unduly high potency is obtained if the adsorbed quaternary compound is not actively if the formation of clumps is prevented. The maintenance of virulence by the survivors also supports this hypothesis.

On the basis of laboratory tests it is felt that the use of Cetavlon at a concentration of $0.1 \%$ should be adequate as a general antiseptic, provided that the volume of antiseptic solution is ample to overcome the neutralizing action of any organic matter present.

The failure of Cetavlon to kill bacterial spores means that the compound cannot be used for the sterilization of surgical instruments.

Table 5. The bactericidal action of $1.0 \%$ Cetavlon in the presence of $90 \%$ horse blood

Time of exposure

$\begin{array}{rrr}\text { (min.) } & \text { Ps. pyocyanea } & \text { Bact. coli } \\ 0 & 20,000,000 & 80,000,000 \\ 2 & 60,000 & 60,000 \\ 5 & 3,000 & 1,200 \\ 15 & 2,400 & 600 \\ 60 & 3,000 & 52\end{array}$

Staph. aureus
$2,000,000,000$
0
0
0
0

Strep. pyogenes

$700,000,000$

0

0

0

Table 6. The bactericidal action of $0.1 \%$ Cetavlon on Streptococcus agalactiae in the presence of milk

\begin{tabular}{|c|c|c|c|c|c|c|c|c|c|}
\hline \multirow{2}{*}{$\begin{array}{c}\text { Time of } \\
\text { exposure } \\
\text { (min.) }\end{array}$} & \multicolumn{3}{|c|}{ No milk } & \multicolumn{3}{|c|}{$10 \%$ milk } & \multicolumn{3}{|c|}{$50 \%$ milk } \\
\hline & $\begin{array}{c}\text { Strain } \\
\text { C3B }\end{array}$ & $\begin{array}{l}\text { Strain } \\
\text { A } 2\end{array}$ & $\begin{array}{c}\text { Strain } \\
\text { JD } 8\end{array}$ & $\begin{array}{c}\text { Strain } \\
\text { C3B }\end{array}$ & $\begin{array}{c}\text { Strain } \\
\text { A } 2\end{array}$ & $\begin{array}{c}\text { Strain } \\
\text { JD } 8\end{array}$ & $\begin{array}{c}\text { Strain } \\
\text { C3B }\end{array}$ & $\begin{array}{c}\text { Strain } \\
\text { A2 }\end{array}$ & $\begin{array}{c}\text { Strain } \\
\text { JD } 8\end{array}$ \\
\hline 0 & $14 \times 10^{6}$ & $1 \times 10^{6}$ & $800 \times 10^{6}$ & $14 \times 10^{6}$ & $1 \times 10^{6}$ & $800 \times 10^{6}$ & $14 \times 10^{6}$ & $1 \times 10^{6}$ & $800 \times 10^{6}$ \\
\hline 2 & 0 & 0 & 0 & 24,000 & 0 & 60 & $3 \times 10^{6}$ & 700,000 & $18 \times 10^{6}$ \\
\hline 5 & 0 & 0 & 0 & 0 & 0 & 0 & 400,000 & 400,000 & $3 \times 10^{6}$ \\
\hline 15 & 0 & 0 & 0 & 0 & 0 & 0 & 200,000 & 33,000 & 400 \\
\hline
\end{tabular}

Note. Blood agar plates were used to culture the survivors. Lubrol W is itself a haemolytic agent, and when it was used in the tests with this organism the results were confusing as the organism grew poorly on blood lysed by Lubrol W although in broth their growth was not affected by this substance. Horse serum (20\%) is equally effective in breaking up the clumps of bacteria and in neutralizing the bacteriostatic action of Cetavlon, and was therefore used instead of Lubrol $W$ in tests on this organism only.

removed from the treated organisms. Such inhibited cells of course die eventually but they are not killed immediately, as the results seem to indicate. On the other hand, the presence of a few survivors may make it appear that none of the cells has been killed if the test is so conducted that only presence or absence of bacterial growth is noted. In our own study the survival time of the organisms has been recorded after they have been freed from adsorbed quaternary compound. An additional complication in studies of death-rate is caused by the fact that cells surviving the action of quaternary compounds are formed into clumps thus giving rise to many fewer colonies than there are survivors. When these errors are avoided it can be shown that even very dilute solutions of quaternary compounds cause a very rapid and very marked decline in viable population. A few cells survive a much longer period of contact. These cells are probably those inside the clumps and have not received a lethal dose of the compounds since there are very few survivors

\section{SUMMARY}

1. Some sources of error in the testing of quaternary ammonium compounds for bactericidal activity have been investigated. These resolve themselves into $(a)$ errors caused by bacteriostasis, and $(b)$ errors caused by the clumping of bacteria.

2. A suitable technique, free from these errors, is described.

3. Cetavlon in $0 \cdot 1 \%$ solution is a powerful bactericide even in the presence of moderate amounts of organic matter.

4. One per cent Cetavlon will not kill spores at room temperature even when contact is maintained for several days.

5. Bacteria surviving the action of quaternary ammonium compounds retain their virulence.

The author wishes to express his gratitude to Dr A. R. Martin for his helpful criticism and to Miss B. Y. Barlow for her valuable technical assistance. 


\section{REFERENCES}

BARNeS, J. M. (1942). Lancet, 1, 531-2.

Blubaugh, L. V., Grewe, E. G., Botts, C. W. \& Helvig, H. L. (1940). J. Bact. 41, 34-5.

Davies, G. E. \& FishbuRN, A. G. (1946). Quart. J. Pharm. Pharmacol. 19, 365-72.

Domagk, G. (1935). Dtsch. Med. Wschr. 61, 829-32.

Du Bors, A. S. (1947). Soap and San. Chem. 23, 139.

Do Bois, A. S. \& Dibblete, D. (1946). Science, 103, 734.

Du Bois, A. S. \& Dibblee, D. (1947). Quoted by Du Bois, 1947.

Graydon, J. J. \& Biggs, C. L. (1942). Med. J. Aust. 2, 513-15.

Green, T. W. \& Birkeland, J. M. (1941). J. Bact. 41, 34.

Heinemann, P. G. (1937). J. Amer. Pharm. Ass. 26, 711-17.

Kenner, B. A., Quisno, R. A., Foter, M. J. \& Gibby, I. W. (1946). J. Bact. 52, 449-51.

Kivela, E. W., Mallmann, W. L. \& Churchinl, E. S. (1948). J. Bact. 55, 565-72.

KLARMANn, E. G. \& Wright, E. S. (1946). Soap and San. Chem. 22, 125.
Klarman, E. G. \& Wright, E. S. (1948). Amer. J. Pharm. 120, 146-57.

Mallmann, W. L. \& Hanes, M (1945). J. Bact. 49, 528.

Mallmann, W. L. \& Leaviti, A. H (1948). Amer. J. Vet. Res. 9, 104-8.

McCuLloch, E. C. (1947). Science, 105, 480-1.

McCulloch, E. C., Hauge, S. \& Migaki, H. (1948a). J. Amer. Vet. Med. Ass. 112, 283-90.

McCulloch, E. C., Hauge, S. \& Migaki, H. (1948b). Amer. J. Publ. Hlth, 38, 493-503.

Mmler, C. P. (1942). Amer. J. Publ. Hlth, 49, 197.

NAGEL, A. (1940). München. Med. Wschr. 1, 970.

Quisno, R. A. \& Foter, M. J. (1946). J. Bact. 52, $111-$ 17.

Quisno, R. A., Foter, M. J. \& Rubenkoenig, H. L. (1947). Soap and San. Chem. 23, 145.

Quisno, R. A., Grbby, I. W. \& Foter, M. J. (1946a). J. Amer. Pharm. Ass. 35, 317-19.

Quisno, R. A., GibBy, I. W. \& Foter, M. J. (1946b). Amer. J. Pharm. 118, 320-3.

VALKo, E. I. \& DU Bors, A. S. (1944). J. Bact. 47 15-25.

(MS. received for publication 3. v. 49.-Ed.) 